\title{
A dystrophia myotonica l-es típusának sokszervi megjelenése
}

\author{
Varga Dávid dr. ${ }^{1}$ - Pál Endre dr. ${ }^{1,2}$ \\ ${ }^{1}$ Pécsi Tudományegyetem, Általános Orvostudományi Kar, Klinikai Központ, Neurológiai Klinika, Pécs \\ ${ }^{2}$ Pécsi Tudományegyetem, Általános Orvostudományi Kar, Neuropathologiai Tanszék, Pathologiai Intézet, Pécs
}

\begin{abstract}
A dystrophia myotonica az egyik leggyakoribb felnőttkori, autoszomális domináns módon öröklődő izombetegség. Két típusa ismert, az l-es típusban distalis izomtünetek és myotonia alakul ki, a 2 -es típust enyhébb izomtünetek és proximalis dominancia jellemzi. A szerzői néven Steinert-betegségként ismert kórkép a vázizomrendszeren túl elsősorban a szív ingerületképző és -vezető rendszerét, a belső elválasztású mirigyek múködését, a szénhidrát- és zsíranyagcserét, a szemlencsét, valamint az ivarmirigyek funkcióját érinti. Az izmok károsodásának tünettana mellett megjelenő egyéb szervi kórállapotok a betegek életminőségét és túlélését jelentősen befolyásolják. Ezért tartjuk szükségesnek, hogy e szempontok figyelembevételével végezzük izombetegeink neurológiai gondozását. Közleményünkben igyekszünk kiemelni e multiszisztémás jellegű betegség klinikai megjelenésének főbb pontjait, valamint a diagnosztikai lehetőségek eszköztárát. Következtetéseink támpontot adhatnak a fenti kórképpel diagnosztizált betegek gondozását végző orvosok számára, az egyénre szabott követés megvalósításához.
\end{abstract}

Orv Hetil. 2019; 160(37): 1447-1454.

Kulcsszavak: cataracta, dystrophia myotonica, inzulinrezisztencia

\section{Multiorgan manifestations in myotonic dystrophy type 1}

Myotonic dystrophy is one of the most common, autosomal dominantly inherited adult-onset muscle disorders. Two types of the disease are known: type 1 is characterized by distal weakness and myotonia, but type 2 is associated with proximal weakness and milder clinical course. It is also called as Steinert Disease, which affects the heart conduction system, the internal secretional glands, the ocular lens as well as carbohydrate-, fat metabolism and gonadal functions. These systemic symptoms have high impact on the quality of life and might impact on patients' survival. Here we would like to emphasize these clinical conditions and the diagnostic possibilities. We hope our recommendations can help neurologists and general practitioners to achieve an optimal and individual care for patients suffering from this muscle disease.

Keywords: cataract, myotonic dystrophy, insulin resistance

Varga D, Pál E. [Multiorgan manifestations in myotonic dystrophy type 1]. Orv Hetil. 2019; 160(37): 1447-1454.

(Beérkezett: 2019. április 15.; elfogadva: 2019. május 5.)

\begin{abstract}
Rövidítések
$6 \mathrm{MWT}=($ six-minute walk test $) 6$ perces járásteszt; $10 \mathrm{mWT}$ $=(10-\mathrm{m}$ walk test $) 10$ méteres járásteszt; $\mathrm{ACTH}=($ adrenocorticotropic hormone) adrenokortikotrop hormon; BMI = (body mass index) testtömegindex; CCTG = citozin-citozintimin-guanin; $\mathrm{CICl}=$ (muscle-specific chloride ion channel) a kloridion-csatorna részeként funkcionáló fehérje; CTG $=$ citozin-timin-guanin; DMl = a dystrophia myotonica l-es típusa; $\mathrm{DMPK}=$ dystrophia myotonica proteinkináz; $\mathrm{EKG}=$ elektrokardiográfia; EMG = elektromiográfia; FEVI = (forced expiration volume in one second) kényszerített kilégzési mennyi-
\end{abstract}

ség egy másodperc alatt; FGF21 = (fibroblast growth factor 21) fibroblastnövekedési faktor-21; FRC $=$ (functional residual capacity) funkcionális maradványkapacitás; $\mathrm{FVC}=$ (forced vital capacity) kényszerített vitálkapacitás; $\mathrm{HDL}=$ (high-density lipoprotein) magas sürüségü lipoprotein; HOMA-IR = (homeostatis model assessment - estimated insulin resistance) a homeosztázismodell alapján becsült inzulinrezisztencia; HPA = (hypothalamic-pituitary-adrenal) hypothalamus-hypophysismellékvese; IGT = (impaired glucose tolerance) csökkent glükóztolerancia; IR = inzulinreceptor; LDL = (low-density lipoprotein) alacsony sûrüségü lipoprotein; MIRS = (muscular 
impairment rating scale) izomkárosodás besorolása; MRC = (Medical Research Council) Orvosi Kutatási Tanács; MRI = (magnetic resonance imaging) mágnesesrezonancia-képalkotás; mRNS = (messenger RNA) hírvivő RNS; NAFLD = (nonalcoholic fatty liver disease) nem alkoholos zsírmájbetegség; $\mathrm{NHPT}=$ (nine-hole peg test) kilenclyukú pálca teszt; NIV = (non-invasive ventilation) nem invazív lélegeztetés; OSAS = (obstructive sleep apnea) obstruktív alvási apnoe; PROMM = proximalis myotonic myopathia; RNS = ribonukleinsav; RV = (residual volume) maradék térfogat; $\mathrm{SDB}=$ (sleep-disordered breathing) alvásfüggő légzészavar; STIR $=$ (short-time inversion recovery) rövid inverziós helyreállítás; TLC = (total lung capacity) teljes tüdőkapacitás; $\mathrm{VC}=$ (vital capacity) vitálkapacitás; ZNF9 = (zinc finger protein 9) cinkujjfehérje-9

\section{A dystrophia myotonica genetikai háttere}

A dystrophia myotonica (DM) az egyik leggyakoribb felnőttkori, autoszomális domináns módon öröklődô izombetegség. Gyakorisága 0,5-18,1/100 000, ez nálunk kb. 10/100 000 gyakoriságot jelent [1]. Az l-es típusának hátterében a 19. kromoszómán elhelyezkedő DMPK - (dystrophia myotonica protein kinase) gén $3^{\prime}$ végén megjelenő CTG trinukleotid expanziója áll, azaz a gén szekvenciasorában CTG-ismétlődések jelennek meg, melyek száma nagy variációt mutat az egyes páciensekben. Az ún. 2-es típusú DM esetében a 3. kromoszóma ZNF9- (zinc finger protein 9) génjében megjelenó CCTG tetranukleotid ismétlődése azonosítható.

Mindkét esetben fehérjét nem kódoló - azaz transzkriptálódó, de nem transzlálódó - régióban elhelyezkedô mutációról van szó, amely így arra enged következtetni, hogy elsősorban transzkripciós zavar, és nem közvetlen fehérjekárosodás felelős a betegségért. Természetesen a fehérjekárosodás megkerülhetetlen, másodlagos következménye a folyamatnak [2].

Jól ismert, hogy a génben megjelenő CTG-ismétlődések száma felelős a klinikai kép súlyosságáért. RakočevićStojanović és mtsai leírták az anticipáció jelenségét DMlben szenvedő betegek esetében, ami azt jelenti, hogy minden következő generációban fiatalabb korban és súlyosabb tünetekkel jelentkezik a betegség, mint az elődök esetén [3].

\section{Patomechanizmus}

Az említett mutáció a gén aminosavat nem kódoló részében helyezkedik el, így elsősorban a transzkripció során okoz problémát, azaz olyan struktúrájú messenger RNS (mRNS-) molekula keletkezik, amely aztán nem képes a megfelelő poszttranszkripciós modifikáción, ún. splicing mechanizmuson keresztül érett RNS-sé válni. Ennek első számú következménye, hogy az érintett RNS-molekula nukleocitoplazmatikus transzportja elmarad, így nem történik transzláció a citoplazmában, ezért a fehérjeszintézis is zavart szenved. A kóros szerkezetû DMPK-mRNS a magban RNS-kötő fehérjékhez kötődik (például MBNLl), ezáltal számos más, külön- böző szervek esetében strukturális és funkcionális szerepet betöltő fehérjét kódoló mRNS érését is befolyásolja. Ezek közé tartozik például a troponin $\mathrm{T}$ (TNNT2, TNNT3), a kloridcsatorna génjei (például CICl [musclespecific chloride ion channel]) és az inzulinreceptor (IR)-mRNS, ilyen formán magyarázatot szolgáltatva a betegség sokszervi érintettségére és a klinikai tünetek széles spektrumára [4]. Holt és mtsai 2007-ben immunhisztokémiai technikák alkalmazásával kimutatták az MBNLl fehérje és a kóros mRNS-ek intranukleáris akkumulációját DMl-betegekben [5].

\section{Klinikai kép}

A dystrophia myotonica klasszifikációja nem egyértelmú, időról időre jelennek meg újabb, egymástól jelentôsen eltérő osztályozási rendszerek, melyek különböző molekuláris és klinikai szempontokat vesznek figyelembe. Célszerú azonban a kórképet - az egyszerúbb megközelítés és átláthatóság érdekében, elsősorban genetikai alapon - két nagy csoportra osztani, úgymint l-es (DMl) és 2-es (DM2) típusú dystrophia myotonica, a korábban részletezett mutációknak megfelelően.

A 2 -es típus általában későbbi életkorban kezdődik, az izomérintettség enyhébb, és proximalis hangsúlyú, ez háttérbe szorul a többi, szisztémás tünet, azon belül is fóként a szénhidrát-anyagcsere, valamint endokrinológiai eltérésekhez képest. Ebből fakad, hogy sok esetben nem merül fel az izombetegség lehetősége a beteg differenciáldiagnosztikája során.

Az l-es típus jellemzője, hogy a klinikai képet az izomtünetek uralják, elsősorban a progrediáló izomgyengeség és a myotonia. A betegség életkori megjelenésének, súlyosságának, a progresszió sebességének függvényében további három alcsoportot különböztethetünk meg, így kongenitális, típusos felnőttkori és aszimptomatikus dystrophia myotonicáról beszélhetünk.

A kongenitális forma már a születéskor súlyos generalizált izomhipotóniával, izomgyengeséggel, szopási nehezítettséggel társul. Típusos fenotípusbeli eltérés az ún. halszáj, azaz a felső ajkak fordított $V$ alakú megjelenése. Már korán megjelenik a légzési elégtelenség és a gépi ventiláció igénye, ugyanakkor a felnőttkori forma egyik vezető tüneteként említhetô myotonia általában nincs jelen [6].

A felnőttkori forma két fó jellegzetessége a distalis izomgyengeség, valamint a myotonia. Ez utóbbi az izmoknak a kontrakciót követóen megjelenó relaxációs zavarát (csökkent képességét) jelenti, ami így a mindennapi életben az egyik legnagyobb problémát okozza a betegségben szenvedő pácienseknek. Eddigi ismereteink alapján a tünet hátterében egy, a kloridion-csatorna részeként funkcionáló fehérje, a CICl mRNS-ének károsodása állhat [7]. Az izmok mellett számottevő belszervi eltérés is kialakulhat, amelyek az életminőséget és a túlélést is jelentősen csökkentik. Ezek közül elsősorban a szív ingerképző és ingervezető rendszerének zavarai, a 
szürke hályog, a szénhidrát- és lipidanyagcsere kisiklása, a belső elválasztású mirigyek funkciójának károsodása emelendő ki.

Az aszimptomatikus forma klinikai képe a felnőttkoritól lényegében nem tér el, a tünetek azonban jóval enyhébb formában, későbbi életkorban jelentkeznek, sok esetben nem kerülnek diagnózisra. Fontossága abban van, hogy az anticipáció jelenségének ismeretében számíthatunk arra, hogy aszimptomatikus DMl-ben szenvedő személyek leszármazottjainál már súlyosabb klinikai kép várható.

\section{Izomérintettség és hisztopatológia}

A felnőttkori DMl vezető tünete az izomgyengeség és a myotonia. Az izomgyengeség és -atrophia distalis hangsúlyú, a szorítóerő csökkenésében, valamint a lábfej emelésének nehezítettségében jelenik meg, mely utóbbit a klinikumban gyakorta „esőlábnak” nevezzük; következménye a „szteppelő járás”. Emellett az arcizomzat sorvadása jellegzetes képet kölcsönöz a betegnek, melyet facies myopathicának nevezünk. Ennek jegyei az előemelkedő ajkak, csökkent buccalis izomzat, beesett arc és ptosis, melyhez jellegzetes frontalis kopaszodás társul.

A myotonia gyakorta az első tünet, amellyel a beteg orvoshoz fordul. Az érintett izmok (elsősorban a kéz izmai) relaxációs képességének csökkenése miatt a beteg a behajlított ujjakat nem képes kinyújtani, az ökölbe szorított kezet kinyitni. Nem minden beteg esetén látunk kifejezett spontán myotoniát, különösen a betegség kezdeti szakaszán, de a percussiós myotonia már ilyenkor is gyakorta látható. Az alsó végtagi izomzat myotoniájának következménye, hogy a betegek - sokszor gyermekkortól - képtelenek futni, bár izomerejük megtartott.

A betegségtartam növekedésével az izmok átalakulásában a kezdeti zsíros degeneráció helyét egyre inkább az atrophia veszi át, szembetűnővé válik a végtagok elvékonyodása, az arcizmok mennyiségének csökkenése, a járás- és rágásnehezítettség, a fizikai aktivitás jelentős csökkenése. A folyamat MRI-vizsgálatokkal is követhető: Tl-felvételeken elsősorban az atrophia, míg FatSaturated-képeken a zsíros degeneráció szembetűnő; az aktív degeneráció és ödéma a STIR-felvételeken látható. A jelenséget mellékelt ábránkon, klinikánk gondozásában lévő DM-betegek végtagfelvételeivel szemléltetjük (1. ábra).

A diagnosztika egy fontos eleme az izmokból nyert minták patológiai módszerekkel történő feldolgozása. A DMl-re jellemző karakterisztikus szövettani kép gyakran önmagában is elegendő lehet a diagnózis felállításához, de az eredményt genetikai vizsgálattal verifikálni kell. A hisztológiai leletre jellemző, hogy nagy variabilitást mutat az izomrostok átmérője, mely néhány mikrométeres átmérőtől a 100 mikrométerig változhat (a normális érték felnőtt nőknél 30-70 $\mu \mathrm{m}$, férfiaknál 40-80 $\mu \mathrm{m})$. Az atrophiás rostok kerekek, szórványosan helyezkednek el. A patológia másik jellemző vonása, hogy a

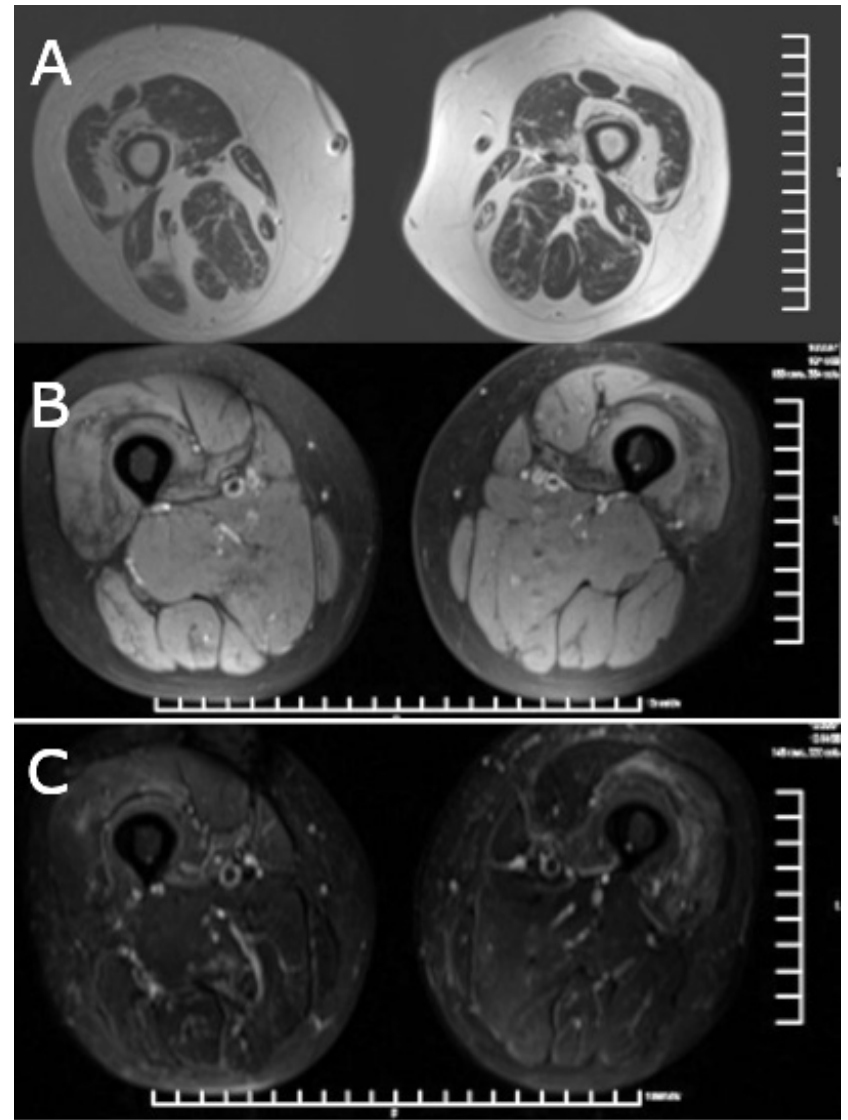

1. ábra DMl-betegek comb-MRI-felvételei
Az alsó végtagon, a comb középső harmadában készült axialis
MRI-felvételek. (A) Tl-súlyozott felvételen dominál a musculus
quadriceps femoris részleges, félhold alakú zsíros degenerációja,
emellett a térdhajlító izmok atrophiája és foltos degenerációja is
megfigyelhető a hátsó kompartmentben. (B) FatSaturated-fel-
vétel, az érintett területek sötéten ábrázolódnak. (C) STIR-fel-
vétel az aktív degeneráció/ödéma megjelenítésére alkalmas,
a m. quadricepsben látszik foltos jelfokozódás
MRI = mágnesesrezonancia-képalkotás; STIR = rövid inverziós
helyreállítás

magok nagy számban centralizáltak. Ez az arány az egészséges izomban 3\% alatti, míg DM-ben akár 50$80 \%$-os értékkel is találkozhatunk, sőt a hypertrophiás rostokban több belső mag is előfordulhat. A szövettani képet a regenerálódó, bazofil festődésû rostok, a hasadt rostok, valamint a fibrosis és a zsírdepozíció együttes jelenléte teszik változatossá. Ugyancsak jellemző a korábban már említett intranukleáris depozíciók jelenléte. DMl esetében az izomrostok atrophiája kapcsán elsősorban az I-es típusú rostok érintettsége dominál (2. ábra).

A leírt jellemző izompatológia segíthet a diagnosztikában, a mindennapi gyakorlatban azonban nem szükséges izombiopszia készítése, mivel típusos tünetek esetén genetikai vizsgálat bizonyíthatja a betegség fennállását. A DMl genetikai vizsgálata Magyarországon is elérhető, a DM2-vizsgálat csak külföldi genetikai laborokban lehetséges. 


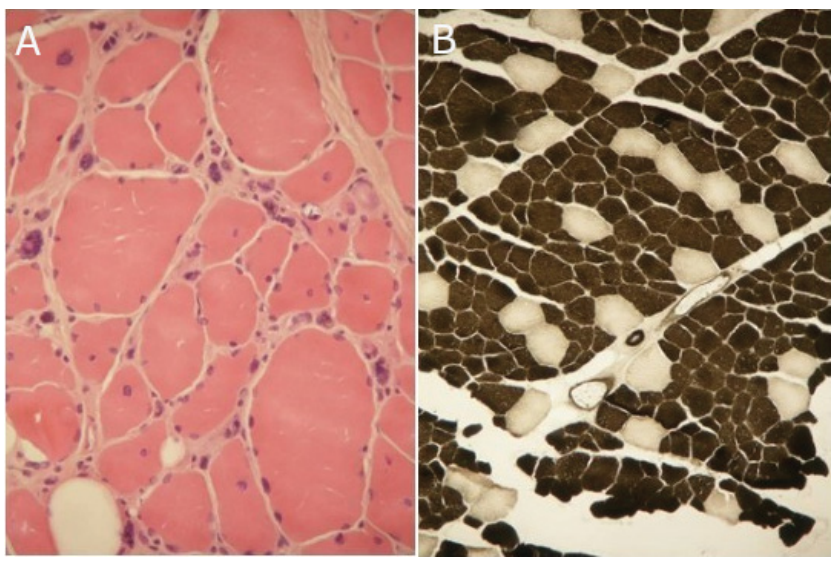

2. ábra

Izompatológia DMl betegségben

DMl-beteg izombiopsziás mintája ( $\mathrm{m}$. tibialis anterior). (A) Jó látható az izomrostok változó mérete, nagyszámú belső mag jelenléte. Egyes rostok olyan mértékben atrophiásak, hogy csak piknotikus magcsoport látszik szarkoplazma nélkül (bazofil képletek, HE). (B) Az ATP-áz készítményen megfigyelhető az I-es rostok sötét dominanciája, valamint hogy az atrophia elsősorban az I-es rostokat érinti (ATP-áz enzimhisztokémia, pH 4,6)

ATP $=$ adenozin-trifoszfát $; \mathrm{DMl}=$ a dystrophia myotonica 1 -es típusa; $\mathrm{HE}=$ hematoxilin-eozin; $\mathrm{m}$. = musculus

A klinikai gyakorlatban objektív tesztek használata szükséges a betegek izomstatusának követésére. A rutinszerűen használt 6 fokozatú izomerőskála (Medical Research Council [MRC] Scale for Muscle Strength, 0 és 5 között) csak szisztematikus alkalmazás esetén lehet alkalmas. Erre a célra kifejlesztettek egy betegségspecifikus súlyossági skálát: Muscular Impairment Rating Scale (MIRS). Ez egy 5 fokozatú skála, amely az izomerőcsökkenés súlyosságát jelzi az alábbiak szerint: (1) nincsenek izomtünetek, (2) minimális ptosis, és axialis tünetek, myotonia, (3) distalis gyengeség, (4) enyhe proximalis gyengeség, (5) súlyos proximalis gengeség jelei [8]. A dinamometria pontosabb mérést tesz lehetővé, de szintén tartalmaz szubjektív elemeket. Objektív funkcionális teszt a felső végtagokra a 9 lyukú pálca teszt (NHPT, nine-hole peg test), az alsó végtagokra a 10 méteres járásteszt ( $10 \mathrm{mWT})$, a 6 perces járásteszt ( $6 \mathrm{MWT})$; az első kettőnél a teszt időtartamának megnyúlása, a harmadiknál a megtett távolság csökkenése jelzi a motoros funkciók romlását. A myotonia mérésére 10 tenyérnyitás idejének mérése használható. A járásteszt eredményét természetesen a cardialis és pulmonalis állapot is befolyásolja [9].

\section{Központi idegrendszeri elváltozások}

Több tanulmányban is vizsgálták a DM-betegek agyi elváltozásait, így például Bielen és mtsai, akik másokhoz hasonlóan nem specifikus periventricularis és subcorticalis fehérállományi laesiókat írtak le [10].

\section{Cataracta mint a DM leggyakoribb szemészeti szövődménye}

A cataracta időskorban gyakori betegség, melynek hátterében a lencse transzparenciájának csökkenése áll. Általános megfigyelés, hogy a DMl-betegek esetében már fiatal korban és nemritkán bilateralis formában jelenik meg a szürke hályog. Ennek szemészeti monitorozása és mielőbbi korrekciója javíthatja a betegek életminőségét.

\section{Alvásfüggő légzészavar}

Alvászavarok gyakran fordulnak elő szinte valamennyi neuromuscularis betegség esetén, ezért jelentős szerepet játszanak a betegek életminőségének romlásában. A leggyakoribb alvászavarok DMl-ben: alvásfüggő légzészavar (SDB), hypersomnia és nyugtalanláb-szindróma [11]. Alvásvizsgálatok alapján az obstruktív alvási apnoe (OSAS) előfordulása 69\% volt DMl - és 42\% DM2-betegek között; az összes beteg 28\%-ánál volt szükség nem invazív lélegeztetés (NIV) bevezetésére [12]. Mivel az OSAS számos másodlagos következménnyel járhat (például magas vérnyomás, fejfájás, stroke, kognitív hanyatlás), hangsúlyozzák az alvásvizsgálatok időszakos elkészítését DM-betegeknél.

\section{Pulmonalis funkciózavar}

Az izomerôvesztés nem csak a végtagokat érinti: a betegség egyik meghatározó és termináló tényezője a légzőizomzat érintettségének kapcsán kialakuló krónikus, progresszív jellegű légzési elégtelenség. Elsősorban restriktív jellegü tüdőbetegség képében mutatkozik, az annak megfelelő légzésfunkciós paraméterek progresszív csökkenésével, úgymint VC (vital capacity), TLC (total lung capacity), RV (residual volume), FRC (functional residual capacity). Ezen statikus paraméterek változását arányosan követi a dinamikus paraméterek csökkenése (FVC: forced vital capacity; FEVl: forced expiration volume in one second), így összességében a Tiffeneau-index $(\mathrm{FEVl} / \mathrm{VC} \%)$ normális marad, ami segít elkülöníteni az obstruktív légzési zavaroktól [13]. A fent említett respiratorikus eltérések általánosságban előfordulhatnak szinte valamennyi izombetegség esetében. DMl esetén is felmerült azonban a kérdés, hogy a légzési elégtelenség kifejlődésének kezdete, sebessége milyen faktorokkal áll összefüggésben. Természetesen az életkor előrehaladtával és így a betegségtartam növekedésével a tünetek súlyossága fokozódik. Több tanulmány igazolta, hogy a trinukleotid expanzió mérete meghatározó szereppel bír a betegségkezdet meghatározásában, emellett egyenes arányosság fedezhető fel az izomerôvesztés súlyossága, valamint a pulmonalis funkciók romlása tekintetében is. Egy 215 DM-beteget involváló tanulmányban arra a következtetésre jutottak, hogy a VC-érték csökkenése szignifikáns kapcsolatban áll az (I.) életkorral, a (II.) magasabb BMI-vel, valamint a (III.) CTG-ismétlődések 
számával is [14]. Ezen túlmenően azt is megállapították, hogy az időben megkezdett NIV csökkenti a mortalitást a DM-betegek csoportjában. Megfelelő, a NIV indikációjára vonatkozó kritériumokkal rendelkező DM-betegek esetén, abban a csoportban, amelyikben a NIV bevezetése legalább egy évet késett, szignifikánsan nagyobb volt a halálozás, mint az egy éven belül megkezdett NIV esetén $[14,15]$.

A fenti eredmények jól tükrözik a DMl-betegek követésében a respiratorikus rendszer állapotára vonatkozó, rendszeresen megismételt légzésfunkciós vizsgálatok szerepét, különös tekintettel a statikus légzési paraméterek változásaira. Az adatok arra is rávilágítanak, hogy a légzési paraméterek változásában is multifaktoriális folyamattal van dolgunk, így figyelembe kell venni a beteg életkorát, a genetikai teszt eredményét és a BMI-értéket, személyre szabott beteggondozást kell végeznünk, ideértve az életmódi tanácsadást (például súlycsökkenés), a gyógytorna- és izomerősítő kezeléseket, szükség esetén pedig a NIV időben történő bevezetését szakember segítségével.

\section{Ingerületvezetési zavarok a DMl-es típusban}

A kardiológiai manifesztáció a DMl egyik leggyakoribb belszervi tünete. Már az 1990-es évek végén, Mathieu és mtsai egy tanulmányban 367, DMl-es típusban szenvedő beteg 10 éves követése alapján közölték, hogy 7,3szer nagyobb mortalitás mutatkozott az egészséges személyek csoportjához képest, és ezen halálozás hátterében elsősorban szív- és respiratorikus rendszeri eredet állt. A betegek egy részénél (2-30\%) hirtelen szívhalál alakult ki, mely mögött a feltételezések szerint ventricularis eredetú ritmuszavar (ventricularis tachyarrhythmia, fibrilláció), illetve elektromechanikus disszociáció állt [16]. Petri és mtsai 1828 DMl-beteget involváló metaanalízis alapján arra jutottak, hogy e betegség cardialis manifesztációjában a vezető eltérés az atrioventricularis blokk, amely a betegek $28,2 \%$-ában volt jelen [17].

A fentiek értelmében elsősorban ingerületvezető rendszeri zavarokra számítunk ezeknél a betegeknél, így olyan módszert kell választanunk a betegkövetés kapcsán, amely ezek ellenőrzésére, időben történő felismerésére alkalmas lehet. Költséghatékonyság és noninvazivitás szempontjából kézenfekvő megoldásnak tűnne az elektrokardiográfia (EKG), ennek azonban sem specificitása, sem szenzitivitása nem tûnik elégségesnek. Nem elhanyagolható az sem, hogy a szív ingerületvezetési zavarai vezető okként szerepelhetnek a hirtelen szívhalál kialakulásában, így e zavarokat időben jelző vizsgálat ennek prevenciójában is hatékony lehetne. William J. Groh kutatócsapata a kardiológiai eltérések - különös tekintettel a hirtelen szívhalálra - EKG-prediktibilitását vizsgálta. 406 DMl-beteg esetén a vizsgálatok kezdetekor 96 esetben már észleltek EKG-eltérést. 5,7 éves követés után a leggyakoribb EKG-abnormalitásoknak a pitvari tachyarrhythmiák mutatkoztak [18].

A szív elektromos rendszerének károsodása a legtöbb esetben a szívizomzat sérülésének (ischaemia, infekció utáni hegesedés), valamint a szívizom strukturális átalakulásának (zsírdepozíció, fibrosis) következtében alakul ki, ezek az elváltozások ugyanis a myocardium ingerületvezető képességét jelentősen megváltoztatják, így az ingerképzés tekintetében autonóm területek alakulhatnak ki, öngerjesztő körök - ún. triggermechanizmus - jöhetnek létre. Ezen eltérések is társulhatnak dystrophia myotonicához, azonban jóval kisebb gyakorisággal, mint az ingerületvezetési zavarok - ezek megítélésére a szív-MRI alkalmas [19].

$\mathrm{Az}$ ingerületvezetési zavarok tehát egyértelmúen zászlóvivőnek tûnnek a DM szívérintettsége tekintetében, az elváltozások sokfélesége azonban egyelőre megnehezíti egy olyan esetleges szürőprogram kialakítását, amely megfelelő szenzitivitás és specificitás mellett a kardiológiai eltérések időben történő felismerését lehetővé tenné, a hirtelen szívhalál előfordulásának - és így a DM halálozási arányának - csökkentése érdekében. Több tanulmány is van folyamatban a szív ingerületvezetésének intervencionális vizsgálatára, a ritmuszavarok tartós monitorozására, a szívüregek, a myocardium funkcionalitásának képalkotó (ultrahang- vagy MRI-) vizsgálatára és prediktív biomarkerek azonosítására.

\section{Anyagcsere-változások - előtérben az inzulinrezisztencia}

A kórképhez társuló anyagcsere-eltérések közül elsősorban az inzulinrezisztenciát, valamint a lipidanyagcsere zavarait kell említenünk.

Az inzulinrezisztencia hátterében - ahogy arra korábban is utalást tettünk - elsősorban az IR-fehérjét kódoló mRNS splicing mechanizmusának zavara állhat. Következménye az inzulinra adott celluláris válaszkészség csökkenése, az inzulinrezisztencia és a következményes IGT (impaired glucose tolerance) kialakulása. Ez - kezdetben legalábbis - egyszerre emelkedett széruminzulinés -glükózszintekkel jár, így ennek a két értéknek az emelkedése már jelezheti az inzulinrezisztencia fennállását. A klinikai gyakorlatban a HOMA-IR (homeostatis model assessment - estimated insulin resistance) alkalmas az inzulinrezisztencia megállapítására. Megalkotása Matthews és mtsai nevéhez kötődik [20]. Kiszámítása: HOMA-IR $=($ éhomi vércukor $[\mathrm{mM} / \mathrm{l}] \times$ éhomi inzulin $[\mathrm{pmol} / \mathrm{l}]) / 156[21,22]$. Ezek rutin laboratóriumi módszerekkel meghatározhatók, így a fenti képlet a klinikai praktikumban könnyen használható a betegkövetés során. Egy tanulmány keretében 34, dystrophia myotonicával diagnosztizált beteg esetén meghatározott HOMA-IR-értéket vetettek össze 34 egészséges személyével. Az eredmények szignifikánsan nagyobb értékeket mutattak az izombetegcsoportban (a HOMA-IR átlagértéke 4,23 $\pm 2,43$ volt), mint az egészséges csoportban, 
ahol az átlagérték a normáltartományban $(<4,0)$ helyezkedett el [22]. Munkacsoportunk is hasonló eredményre jutott: betegeink 36\%-ában találtunk emelkedett HOMA-IR-értéket [23].

Valószínű, hogy az inzulinrezisztencia kialakulásának megértése és alapos feltérképezése még hosszú kísérletek sorát igényli; egyfajta rendszerbetegségként tekinthetünk rá, amelyben számos, eddig csak részben ismert funkcióval rendelkező molekula károsodásának következménye vezet funkciókárosodáshoz. Számos vizsgálat történt, amelynek során a szénhidrát-anyagcsere szabályozásában részt vevő molekulák szerepét igyekeztek felderíteni (például FGF21, irizin), esetleges biomarkerszerepüket megbecsülni az egyes izombetegségekhez társuló belgyógyászati kórállapotok kialakulásának időben történő észlelése céljából [24, 25]. Az FGF21 és az irizin a szénhidrát-anyagcsere mellett a zsírsavak anyagcseréjének is résztvevői. DM-ben jellemző eltérés a hypertriglyceridaemia, az alacsony HDL- és magas LDLkoleszterin-szint, valamint a visceralis zsírakkumuláció [24, 26]. Kiemelnénk a HDL- és LDL-értékek atherogen eltolódását: ezek jól ismerten az alapját képezik a coronariák szűkuületének, elzáródásának és így az ischaemiás szívbetegség kialakulásának, melynek egyik következménye lehet a szívizom hegesedése, s ez alapot teremthet a reentry mechanizmus talaján megjelenő szívritmuszavaroknak.

Egyes DM-betegek esetében zsírmáj (NAFLD, nonalcoholic fatty liver disease) alakul ki, ennek mechanizmusát vizsgálják.

\section{A belső elválasztású mirigyek diszfunkciói DM-betegekben}

Ritkábban kerülnek említésre a betegséghez társuló, a belső elválasztású mirigyek funkcionális zavarából fakadó kórállapotok, pedig a betegek fenotípusbeli kórjeleinek kialakításában (például korai frontalis kopaszodás), valamint az életminőség romlásában is szerepet játszanak. Ezek közül elsősorban a mellékvesekéreg, a herék, valamint a pajzsmirigy (hypothyreosis) funkcionális eltérései alakulnak ki. A mellékvesekéreg-atrophia hypadreniás állapotot okoz, melynek következménye lehet a már többször említett frontalis jellegű korai kopaszodás, valamint a testösszetétel megváltozása, nevezetesen a zsírdepozitumok - elsősorban a visceralis zsír - mennyiségének növekedése, párhuzamosan az izomtömeg csökkenésével. A hypogonadismus hátterében lévő testicularis elváltozások relatíve széles skálán mozognak, az interstitium és a tubularis rendszer morfológiai eltérései egyaránt azonosíthatók [27].

Takeshima munkacsoportja egy 2018-as esettanulmányban a DM-re jellemző jól ismert klinikai eltérések mellett a HPA- (hypothalamic-pituitary-adrenal) tengely múködésének zavarát írta le, amely elsősorban az ACTH (adrenokortikotrop hormon) és a kortizol diurnalis ritmusának abnormalitásában, a kortizolstimuláció során jelentkező ACTH-szekréció-növekedésben, valamint az ACTH adását követően észlelt hiposzenzitív adrenalis cortex válaszban nyilvánult meg. A tesztoszteronhiányra utaló eltérés volt a visceralis zsír felhalmozódása, melyet abdominalis CT-felvétellel igazoltak [28].

Összességében azt mondhatjuk, hogy az endokrinológiai eltérések önmagukban és kombináltan is előfordulhatnak, bonyolult eltéréseket képezhetnek a DM-betegek esetében.

Egy a fenti szervi manifesztációk előfordulási gyakoriságát vizsgáló 2011-es, több mint 100 DMl-betegen végzett tanulmány alapján obesitas $25 \%$-ban, hypertriglyceridaemia $47,6 \%$-ban, diabetes mellitus 17\%-ban fordult elő. Jelentős látásromlást okozó cataracta 43,4\%ban volt kimutatható. Restriktív tüdőbetegség 34\%-ban fordult elő, míg cardialis vezetési zavar 30\%-ban volt jelen. Valamennyi kórkép korrelációt mutatott a MIRSértékkel, valamint kimutatták, hogy a cataracta és a kondukciós zavar jelenléte esetén gyakoribb volt a tüdőérintettség is [29].

\section{Daganatok előfordulása DMl-ben}

A fentieknél még ritkábban esik szó a betegek daganatos kockázatáról; ebben a kérdésben az a legfontosabb, hogy melyek azok a daganattípusok, amelyek szúrésére fokozott előfordulásuk miatt hangsúlyt kellene helyeznünk. Több, a közelmúltban készült tanulmány - különböző összetételü DM-beteg-populációkat vizsgálva - többféle benignus és malignus tumor nagyobb gyakoriságát írta le. 261 DM-beteg (231 DMl, 10 DM2, 20 ismeretlen típusú DM) esetében vizsgálták a tumorok előfordulását az Egyesült Királyságban. Ebben a közleményben az első helyen a bőr carcinomatosus elváltozásait, a második helyen a tüdőrákot jelölték meg a gyakoriság tekintetében [30]. Egy 2018-as metaanalízis során arra jutottak, hogy a DM-betegek esetében egyértelmúen magasabb rizikóval kell számolnunk a pajzsmirigy, az endometrium, a colorectum és a testis malignus tumorai, valamint a cutan melanoma esetén [31].

Tekintve, hogy a DM genetikailag meghatározott betegség, további vizsgálatok szükségesek ahhoz, hogy feltárjuk, milyen kapcsolat állhat fenn a betegség és a társuló tumoros elváltozások között, illetve melyek azok a rizikófaktorok, melyek felismerése és kizárása esetleg hátráltatni képes a tumorok kifejlődését.

\section{A dystrophia myotonica 2-es típusának fóbb klinikai vonásai}

Munkánkban a gyakoribb előfordulás és a súlyosabb neurológiai kép miatt a DMl klinikai aspektusaira helyezzük a hangsúlyt, röviden mégis igyekszünk ismertetni a DM2 legfontosabb vonásait is. A genetikai háttér, ahogy az előzőekben említésre került, eltér a DMl-ben ismert változásoktól: DM2-ben a ZNF9-génben megjelenő 
CCTG tetranukleotid expanziója okozza a tüneteket. További különbség a genetika tekintetében, hogy a DM2 esetében nem tapasztalható anticipáció, valamint nincs korreláció az ismétlődések száma és a klinikai kép súlyossága között [32].

A patomechanizmus hasonló: a DM2 esetében is RNS splicing zavar áll fenn, intranukleáris RNS-fehérje-aggregátumok figyelhetők meg.

A klinikai kép néhány sarkalatos eltérése a következő. Érdekes megfigyelés, hogy a DM2 esetében kongenitális forma nem létezik [33], a kórkép későbbi életkorban és lárváltan kezdődik. A nagyfokú izomtömegvesztés és izomerő-csökkenés, valamint a gyors progresszió nem jellemző, sokkal inkább enyhe fokú izomgyengeség alakul ki, melynek eloszlása is eltérő: a DMl-ben jellegzetes distalis megjelenéssel ellentétben itt elsősorban proximalisan, a végtagövek területén jelenik meg izomgyengeség és -atrophia (korábbi elnevezése ennek megfelelően: PROMM = proximal myotonic myopathy), legalábbis a betegség kezdeti szakaszában. Az extramuscularis eltérések mindkét formában előfordulhatnak, gyakorlatilag hasonlóan nagy variabilitással a DM2 esetén, mint ahogy azt a DMl-nél láthattuk, melynek oka a hasonló patomechanizmus, a splicing zavara mind a két betegségtípusban [34].

Hazánkban a DM2-betegek diagnosztikája nem megoldott, ugyanis hazai laboratóriumban nem végeznek célzott genetikai vizsgálatot, csak a klinikai kép és az elektrofiziológia (EMG) alapján merül fel a betegség fennállása. Ebből kifolyólag a DM2 gyakorisága pontosan nem ismert, a jelenleg feltételezettnél jóval nagyobb lehet. A diagnózis felállítását nehezíti sok esetben az a tény is, hogy az izomgyengeség és izomvesztés enyhe mértéke és lassú progressziója, valamint a myotonia hiánya miatt nem kerülnek a betegek neuromuscularis szakrendelésre. Az 1-es és 2-es típus összehasonlítását szemlélteti az 1. táblázat.

\section{Megbeszélés}

A dystrophia myotonica genetikai eredete ma már jól ismert, a betegséggel kapcsolatos ismereteink azonban a patomechanizmus, illetve a klinikum szempontjából nagy kihívást jelentő társbetegségek tekintetében még meglehetősen hiányosak. Számos társbetegség jelenhet meg az akár több évtizedes betegkövetés kapcsán. Írásunkban megpróbáltuk kiemelni a leggyakrabban elöforduló kórállapotokat, mint a szív ingerképző és ingerületvezető rendszerének zavarait, az endokrinológiai kórállapotokat, az anyagcsere zavarait, valamint a szemészeti és onkológiai eltéréseket. Véleményünk szerint ezek ismerete támpontot adhat a megfelelő, személyre szabott betegkövetés megvalósítására, a betegek rizikófaktorainak felmérésétől a megfelelő preventív és terápiás ezközök kiválasztásáig.

A fentiek alapján, nemzetközi ajánlásokat is figyelembe véve, a neurológiai betegkövetés mellett, rendszere-
1. táblázat $\mid$ A dystrophia myotonica (DM) 1-es és 2-es típusának összehasonlítása

\begin{tabular}{|c|c|c|}
\hline & DMl & DM2 \\
\hline Az érintett gén & $D M P K$ & ZNF9 \\
\hline A mutáció típusa & $\begin{array}{l}\text { A CTG trinukleotid } \\
\text { expanziója }\end{array}$ & $\begin{array}{l}\text { A CCTG tetranukle- } \\
\text { otid expanziója }\end{array}$ \\
\hline Patomechanizmus & \multicolumn{2}{|c|}{ Splicing zavar, multiszisztémás tünettan } \\
\hline Anticipáció & Igen & Nem \\
\hline $\begin{array}{l}\text { Az ismétlődések } \\
\text { száma és a klinikai } \\
\text { kép súlyossága } \\
\text { közötti kapcsolat }\end{array}$ & Egyenes arányosság & Nincs \\
\hline Betegségkezdet & $\begin{array}{l}0-50 \text { év } \\
\text { (általában 20-40 év) }\end{array}$ & 40 év < \\
\hline $\begin{array}{l}\text { Az előtérben lévő } \\
\text { tünetek }\end{array}$ & $\begin{array}{l}\text { Izomgyengeség és } \\
\text { myotonia }\end{array}$ & $\begin{array}{l}\text { Cataracta, endokri- } \\
\text { nológiai eltérések } \\
\text { (például diabetes) }\end{array}$ \\
\hline $\begin{array}{l}\text { Az izomgyengeség } \\
\text { eloszlása }\end{array}$ & $\begin{array}{l}\text { Distalis (kis } \\
\text { kézizmok, plantar- } \\
\text { és dorsalflexio) }\end{array}$ & $\begin{array}{l}\text { Proximalis } \\
\text { (váll- és csípőöv) }\end{array}$ \\
\hline - Facies myopathica & Kifejezett & Enyhe \\
\hline $\begin{array}{l}\text {-A nyakizmok } \\
\text { gyengesége }\end{array}$ & Kifejezett & Kifejezett \\
\hline - Myotonia & Kifejezett & Változó \\
\hline $\begin{array}{l}\text { •Lábszár-hyper- } \\
\text { trophia }\end{array}$ & Nincs & Markáns \\
\hline - Cataracta & Gyakori & Gyakori \\
\hline - Cardialis tünetek & Gyakori & Változó \\
\hline - Légzészavar & Gyakori & Ritka \\
\hline
\end{tabular}

CTG = citozin-timin-guanin $; \mathrm{DM}=$ dystrophia myotonica

sen, évente javasolt a betegek kardiológiai, endokrinológiai és szemészeti szürővizsgálata; mérlegelendő alvásvizsgálat készítése, valamint szükséges a rendszeres onkológiai szűrés, gyanú esetén a tumorkutatás.

Nemcsak a DM, de csaknem az összes izombetegség esetén világszerte aktív kutatómunka folyik génterápiás eljárások kifejlesztésére, ami reményt adhat a közeljövőben elérhető terápiás lehetőségekre. Ugyanakkor egyértelmüen látható, hogy a beteg életminőségének és túlélésének meghatározásában az izomérintettségen túl számos - annál sok esetben súlyosabb problémát okozó - belszervi eltérésre kell odafigyelnünk, így jelenleg ezek időben történő felismerése, a lehetséges preventív lépések megtétele, valamint a kialakult kórállapotok kezelése jelenti a fó kihívást a dystrophia myotonicában szenvedő betegek gondozását végző neurológus és a betegellátásért felelős alapellátó orvos számára.

Anyagi támogatás: A közlemény megírása anyagi támogatásban nem részesült.

Szerzôi munkamegosztás: V. D.: Az irodalmi adatok áttekintése, rendszerezése, a szöveg szerkesztése. P. E.: Az 
irodalmi adatok áttekintése, rendszerezése, a szöveg és az ábrák szerkesztése. A cikk végleges változatát mindkét szerző elolvasta és jóváhagyta.

Érdekeltségek: A szerzőknek nincsenek érdekeltségeik.

\section{Köszönetnyilvánítás}

A munkát a Pécsi Tudományegyetem kutatási alapja (PTE AOK-KA 2018-10) támogatta.

\section{Irodalom}

[1] Theadom A, Rodrigues M, Roxburgh R, et al. Prevalence of muscular dystrophies: a systematic literature review. Neuroepidemiology 2014; 43: 259-268.

[2] Machuca-Tzili L, Brook D, Hilton-Jones D. Clinical and molecular aspects of the myotonic dystrophies: a review. Muscle Nerve 2005; 32: 1-18.

[3] Rakočević-Stojanović V, Savić D, Pavlović S, et al. Intergenerational changes of CTG repeat depending on the sex of the transmitting parent in myotonic dystrophy type 1. Eur J Neurol. $2005 ; 12: 236-237$.

[4] Cho DH, Tapscott SJ. Myotonic dystrophy: emerging mechanisms for DM1 and DM2. Biochim Biophys Acta 2007; 1772: 195-204.

[5] Holt I, Mittal S, Furling D, et al. Defective mRNA in myotonic dystrophy accumulates at the periphery of nuclear splicing speckles. Genes Cells 2007; 12: 1035-1048.

[6] Prendergast P, Magalhaes S, Campbell C. Congenital myotonic dystrophy in a national registry. Paediatr Child Health 2010; 15 : 514-518.

[7] Charlet-B N, Savkur RS, Singh G, et al. Loss of the muscle-specific chloride channel in type 1 myotonic dystrophy due to misregulated alternative splicing. Mol Cell 2002; 10: 45-53.

[8] Mathieu J, Boivin H, Meunier D, et al. Assessment of a diseasespecific muscular impairment rating scale in myotonic dystrophy. Neurology 2001; 56: 336-340.

[9] Gagnon C, Heatwole C, Hébert LJ, et al. Report of the third outcome measures in myotonic dystrophy type 1 (OMMYD-3) international workshop Paris, France, June 8, 2015. J Neuromuscul Dis. 2018; 5: 523-537.

[10] Bielen J, Schepers S, Termote B, et al. Imaging in myotonic dystrophy type 1 - case reports. J Belg Soc Radiol. 2016; 100: 81.

[11] Romigi A, Franco V, Placidi F, et al. Comparative sleep disturbances in myotonic dystrophy types 1 and 2. Curr Neurol Neurosci Rep. 2018; 18: 102.

[12] Bianchi ML, Losurdo A, Di Blasi C. Prevalence and clinical correlates of sleep disordered breathing in myotonic dystrophy types 1 and 2. Sleep Breath. 2014; 18: 579-589.

[13] Respiratory function tests. In: Székely M. (ed.) Basics of pathophisiology. [Légzésfunkciós vizsgálat. In: Székely M. (szerk.) Kórélettani alapok.] Medicina Könyvkiadó, Budapest, 2013; pp. 417-423. [Hungarian]

[14] Boussaïd G, Wahbi K, Laforet P, et al. Genotype and other determinants of respiratory function in myotonic dystrophy type 1 . Neuromusc Disord. 2018; 28: 222-228.

[15] Boussaïd G, Prigent H, Laforet P, et al. Effect and impact of mechanical ventilation in myotonic dystrophy type 1 : a prospective cohort study. Thorax 2018; 73: 1075-1078.
[16] Mathieu J, Allard P, Potvin L, et al. A 10-year study of mortality in a cohort of patients with myotonic dystrophy. Neurology 1999; 52: 1658.

[17] Petri H, Vissing J, Witting N, et al. Cardiac manifestations of myotonic dystrophy type 1 . Int J Cardiol. 2012; 160: 82-88.

[18] Groh WJ, Groh MR, Saha C, et al. Electrocardiographic abnormalities and sudden death in myotonic dystrophy type 1. N Engl J Med. 2008; 358: 2688-2697.

[19] Pelargonio G, Dello Russo A, Sanna T, et al. Myotonic dystrophy and the heart. Heart 2002; 88: 665-670.

[20] Matthews DR, Hosker JP, Rudenski AS, et al. Homeostasis model assessment: insulin resistance and beta-cell function from fasting plasma glucose and insulin concentrations in man. Diabetology 1985; 28: 412-419.

[21] Muniyappa R, Lee S, Chen H, et al. Current approaches for assessing insulin sensitivity and resistance in vivo: advantages, limitations, and appropriate usage. Am J Physiol Endocrinol Metab. 2008; 294: E15-E26.

[22] Rakočević-Stojanović V, Perić S, Lavrnić D, et al. Leptin and the metabolic syndrome in patients with myotonic dystrophy type 1 . Acta Neurol Scand. 2010; 121: 94-98.

[23] Lovadi E, Csereklyei M, Merkli H, et al. Elevated FGF 21 in myotonic dystrophy type 1 and mitochondrial diseases. Muscle Nerve 2017; 55: 564-569.

[24] Takada, H. Lipid metabolism in myotonic dystrophy. In: Takahashi MP, Matsumura T. (eds.) Myotonic dystrophy. Springer, Singapore, 2018; pp. 161-170.

[25] Dozio E, Passeri E, Cardani R, et al. Circulating irisin is reduced in male patients with type 1 and type 2 myotonic dystrophies. Front Endocrinol (Lausanne). 2017; 8: 320.

[26] Pruna L, Chatelin J, Pascal-Vigneron V, et al. Regional body composition and functional impairment in patients with myotonic dystrophy. Muscle Nerve 2011; 44: 503-508.

[27] Vazquez JA, Pinies JA, Martul P, et al. Hypothalamic-pituitarytesticular function in 70 patients with myotonic dystrophy. J Endocrinol Invest. 1990; 13: 375-379.

[28] Takeshima K, Ariyasu H, Ishibashi T, et al. Myotonic dystrophy type 1 with diabetes mellitus, mixed hypogonadism and adrenal insufficiency. Endocrinol Diabetes Metab Case Rep. 2018; pii 17-0143. Doi: 10.1530/EDM-17-0143.

[29] Kaminsky P, Poussel M, Pruna L, et al. Organ dysfunction and muscular disability in myotonic dystrophy type 1 . Medicine (Baltimore) 2011; 90: 262-268.

[30] Alsaggaf R, Wang Y, Marini-Bettolo C, et al. Benign and malignant tumors in the UK myotonic dystrophy patient registry. Muscle Nerve 2018; 57: 316-320.

[31] Emparanza JI, López de Munain A, Greene MH, et al. Cancer phenotype in myotonic dystrophy patients: results from a metaanalysis. Muscle Nerve 2018; 58: 517-522.

[32] Meola G, Cardani R. Myotonic dystrophy type 2: an update on clinical aspects, genetic and pathomolecular mechanism. J Neuromuscul Dis. 2015; 2: S59-S71.

[33] Day JW, Ricker K, Jakobsen JF, et al. Myotonic dystrophy type 2: molecular, diagnostic and clinical spectrum. Neurology 2003; 60: 657-664.

[34] Ranum LP, Day JW. Myotonic dystrophy: clinical and molecular parallels between myotonic dystrophy type 1 and type 2 . Curr Neurol Neurosci. 2002; 2: 465-470.

Pál Endre dr.,

Pécs, Rét u. 2., 7623 e-mail: pal.endre@pte.hu)

A cikk a Creative Commons Attribution 4.0 International License (https://creativecommons.org/licenses/by/4.0/) feltételei szerint publikált Open Access közlemény, melynek szellemében a cikk bármilyen médiumban szabadon felhasználható, megosztható és újraközölhetö, feltéve, hogy az eredeti szerző és a közlés helye, illetve a CC License linkje és az esetlegesen végrehajtott módosítások feltüntetésre kerülnek. (SID_1) 